\title{
Comparison of the interface dentin-endodontic sealer using two SEM magnifications
}

\author{
Comparação da interface dentina-cimento endodôntico \\ usando dois aumentos de MEV
}

\begin{abstract}
Purpose: The aim of this in vitro study was to compare the interface dentin-sealer of two sealers (RealSeal and AH Plus) using two magnifications under Scanning Electron Microscope (SEM).

Methods: The coronal two thirds of eight extracted molars were removed and the dentin surfaces were grounded with the sequential use of \#180 and \#320 SIC paper under water cooling. The samples were divided into two groups of four in accordance to the sealer to be used. The dentin surfaces were treated with $17 \%$ EDTA followed by $5.25 \% \mathrm{NaOCl}$. Cylinders from polyethylene tubes were applied to the dentin surfaces and filled with freshly prepared sealers. Following $2 \mathrm{~h}$ setting and storage at $37^{\circ} \mathrm{C}$ at $100 \%$ humidity for a week, the teeth were cut perpendicularly to allow the visualization of the area containing the hole, thus the interface dentin-sealer. SEM analysis was done at three areas along the interface, at 150x and 1000x.

Results: The repeated measures ANOVA showed no significant differences between the magnifications. AH-Plus displayed significantly more gaps in the interface dentin-sealer than RealSeal. $(P=0.002)$. The increase in magnification, from $150 x$ to $1000 x$, did not allow any additional identification of gaps.

Conclusion: RealSeal produced less gaps than AH Plus. It could be assumed that 150x is good enough to show defects in the interface dentin-sealer.
\end{abstract}

Key words: Sealer; dentin; SEM analysis

\section{Resumo}

Objetivo: Este estudo teve por objetivo comparar a interface dentina-cimento endodôntico de dois cimentos (RealSeal e AH Plus) usando dois aumentos de Microscopia Eletrônica de Varredura (MEV).

Metodologia: Os dois terços coronários de oito molares extraídos foram removidos e as superficies dentinárias foram desgastadas com o uso sequencial de lixas abrasivas 180 e 320, sob refrigeração a água. Os espécimes foram divididos em dois grupos com quatro espécimes cada de acordo com o cimento endodôntico a ser usado e as superfícies dentinárias foram tratadas com EDTA a 17\%, sendo seguido por $\mathrm{NaOCl}$ a 5,25\%. Cilindros obtidos a partir de tubos de polietileno foram colocados sobre as superfícies dentinárias e preenchidos com os cimentos preparados. Após $2 \mathrm{~h}$ de presa de armazenamento a $37^{\circ} \mathrm{C}$ em ambiente com $100 \%$ de umidade por uma semana, os dentes foram seccionados perpendicularmente para permitir a visualização da área contendo o orifício, ou seja, a interface dentina-cimento. A análise por MEV foi realizada em três áreas ao longo da interface com aumentos de 150x e 1000x.

Resultados: $O$ teste de ANOVA para medidas repetidas não mostrou diferenças significativas entre os aumentos de MEV. O cimento AH-Plus mostrou significantemente mais gaps na interface dentina-cimento que o material RealSeal. $(P=0,002)$. A mudança de aumento de MEV de 150x para 1000x não resultou em identificação maior de gaps.

Conclusão: $O$ cimento RealSeal produziu menos gaps que o cimento AH Plus. Pode-se concluir que o aumento de 150x é suficiente para mostrar defeitos na interface dentinacimento endodôntico.

Palavras-chave: Cimento; dentina; análise por MEV

\author{
Liviu Steier ${ }^{\circ}$ \\ Jose Antonio Poli de Figueiredo b \\ Sema Belli c
}

a Warwick Medical School, Coventry, England, United Kingdom

b Pontifical Catholic University of Rio Grande do Sul, Porto Alegre, RS, Brazil

c Department of Endodontics, Faculty of Dentistry, Selcuk University, Konya, Turkey

\author{
Correspondence: \\ José Antonio Poli de Figueiredo \\ Post-Graduate Program in Dentistry \\ Pontifical Catholic University of \\ Rio Grande do Sul - PUCRS \\ Av. Ipiranga 6681 Prédio 6 sala 507 \\ Porto Alegre, RS - Brazil \\ 90619-900 \\ E-mail: jose.figueiredo@pucrs.br
}

Received: Jan 29, 2010

Accepted: April 19, 2010

Conflict of Interest Statement: The authors state that there are no financial and personal conflicts of interest that could have inappropriately influenced their work.

Copyright: (C) 2010 Steier et al.; licensee EDIPUCRS This is an Open Access article distributed under the terms of the Creative Commons AttributionNoncommercial-No Derivative Works 3.0 Unported License. 


\section{Introduction}

The search for adhesive properties on root canal sealers has long been subject of interest for the field of Endodontology. The method of obturation of the root canals by using guttapercha is widely accepted. Gutta-percha does not bond to root dentin therefore must be used with a sealer cement (1) and a sealer must adhere firmly to both root canal wall and the core material to improve sealing ability of the filling (2-4). Resilon has been proposed to form a bond to the dentin wall and the core material (monoblock concept) reducing the interface sealer-core and preventing microbial leakage (5). Methacrylate resin-based sealer of this system (Epiphany or RealSeal; Pentron, Wallingford, CT) is reported to be able to firmly adhere to the Resilon core material (6). The literature shows conflicting results regarding sealing ability and micro-leakage (6-9) and a debate of high level has been installed amongst researchers about the state of the art of this novel technique and what can be achieved as compared to the current gutta-percha and sealer filling techniques (9-11).

Tay et al. (7) have evaluated the ultrastructure of the apical seal in root canals filled with Resilon and AH Plus using environmental SEM and Transmission Electron Microscope (TEM). They found that a hermetic seal could not be achieved as both materials had gap-free and gap-containing regions. A qualitative approach was used in their study. To date, comparative studies using quantitative analysis of the interface dentine-sealer are not available with RealSeal. The magnification is also a variable that may influence the results, but this has not been assessed either.

The aim of this study was to compare RealSeal and AH-Plus in the dentine interface using two SEM magnifications. The null hypothesis was that magnification would not interfere with the results, and that the filling material did not interfere with the presence of gaps.

\section{Methodology}

Eight human third molar teeth were scaled to remove all adhering soft tissue and debris, washed under running tap water, placed in distilled water, and refrigerated at $4^{\circ} \mathrm{C}$. The coronal two-thirds were removed with a low speed diamond saw (Isomet, Buehler Ltd., Lake Bluff, NY) and the exposed dentin surfaces were used. Two $\mathrm{cm}$ in diameter and $2.5 \mathrm{~cm}$ deep plastic cylindrical rings were filled with freshly mixed autoplymerizing polymethyl methacrylate (PMMA-Meliodent, H.Kulzer, Berkshire) and the teeth were embedded keeping the dentin surfaces exposed. After the PMMA had set, dentin surfaces were grounded on a waterirrigated grinding wheel (Buehler Ltd.) with the sequential use of \#180 and \#320 SiC paper. The smear layer of the exposed dentin surfaces was removed by rinsing for three minutes with $17 \%$ EDTA and followed by $5.25 \% \mathrm{NaOCl}$. The teeth were then divided into two groups of four specimens each.

Polyethylene tubes were cut to form $3 \mathrm{~mm}$ high cylinders and these cylinders were used to apply the sealers on to the dentin. The sealers (RealSeal and AH Plus) were mixed according to the manufacturer's instructions, at room temperature at $23^{\circ} \mathrm{C}$ and a humidity of $37 \%$. To eliminate air bubbles, the polyethylene cylinders were filled from the bottom with a plastic instrument and then vibrated for $15 \mathrm{~s}$. The tested sealers were allowed to bench set for $2 \mathrm{~h}$ and then stored at $100 \%$ humidity at $37^{\circ} \mathrm{C}$ for a period of 1 week. A chisel was used to cut parallel to the dentinal surface, perpendicular to the cylinder, contacting the sealer cylinder at its interface with this surface. This allowed the visualization of the interface dentin-sealer.

The specimens were fixed in stubs, dehydrated in an ascending sequence of alcohols (70, 90 and $99.96 \%$, for $5 \mathrm{~h}$ in each), attached to the stubs with the interface dentinsealer upwards, and sputtered (Balzers, Liechtensten) with gold palladium, to a thickness of $150 \AA$. Scanning electron microscopy (SEM) was conducted using a PhilipsXL 20 (Eindhmoven, Netherlands) microscope, operating at $15 \mathrm{kV}$. SEM analysis was done at three equidistant areas randomly selected along the interface, at 150x and 1000x. The observer was blinded to the sealer under analysis. Each area was given a score, from 1 to 10 , in accordance of the percentage of contact area with visible gap: score 1: 0 - 10\%; 2: 11-20\%; 3: $21-30 \%$; 4: 31-40\%; 5: 41-50\%; 6: 51-60\%; 7: 61-70\%; 8: $71-80 \% ; 9: 81-90 \% ; 10: 90-100 \%$.

A repeated measures ANOVA was performed, looking at the influence of the magnification (150x vs 1000x), the sealer (RealSeal vs AH Plus) and the interaction between them.

\section{Results}

The results are summarized in Table 1 and Figure 1. The average gap scores for RealSeal were $1.33 \pm 0.27$ at $150 \mathrm{x}$ magnification and $1.67 \pm 0.47$ at $1000 \mathrm{x}$. The gap scores for AH Plus were $3.33 \pm 0.47$ at $150 \mathrm{x}$ and $3.67 \pm 0.61$ at $1000 \mathrm{x}$.

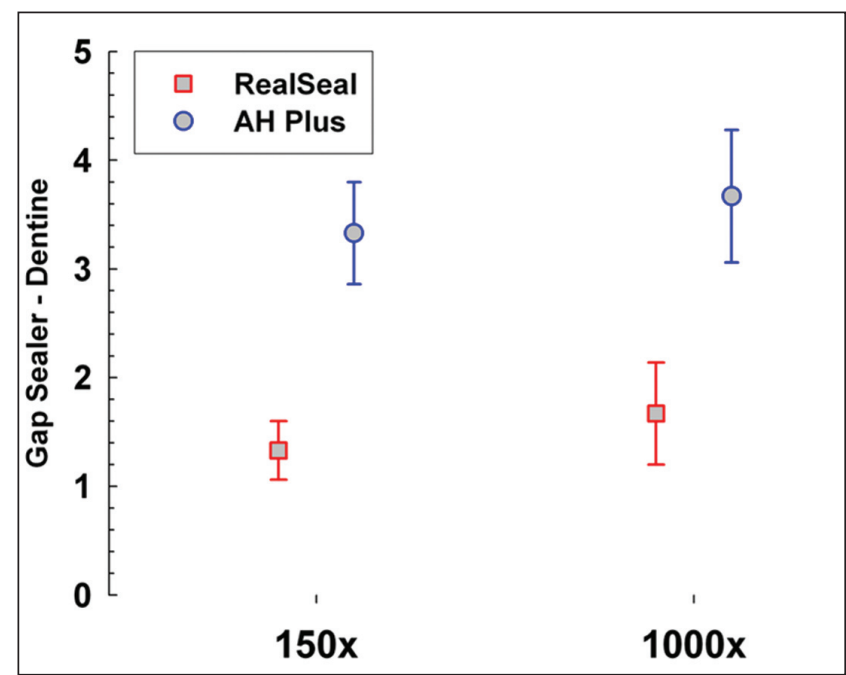

Fig. 1. Average scores of the dentin-sealer gaps, considering the magnifications (150x and 1000x) and the sealers used (RealSeal and $\mathrm{AH}$ Plus). 
There were no statistically significant differences between $150 \mathrm{x}$ and $1000 \mathrm{x}$ magnifications $(P=0.15)$. The sealers displayed significantly different gap sizes, being AH Plus gaps bigger than RealSeal ( $P=0.002)$ (Fig. 2 and Fig. 3).

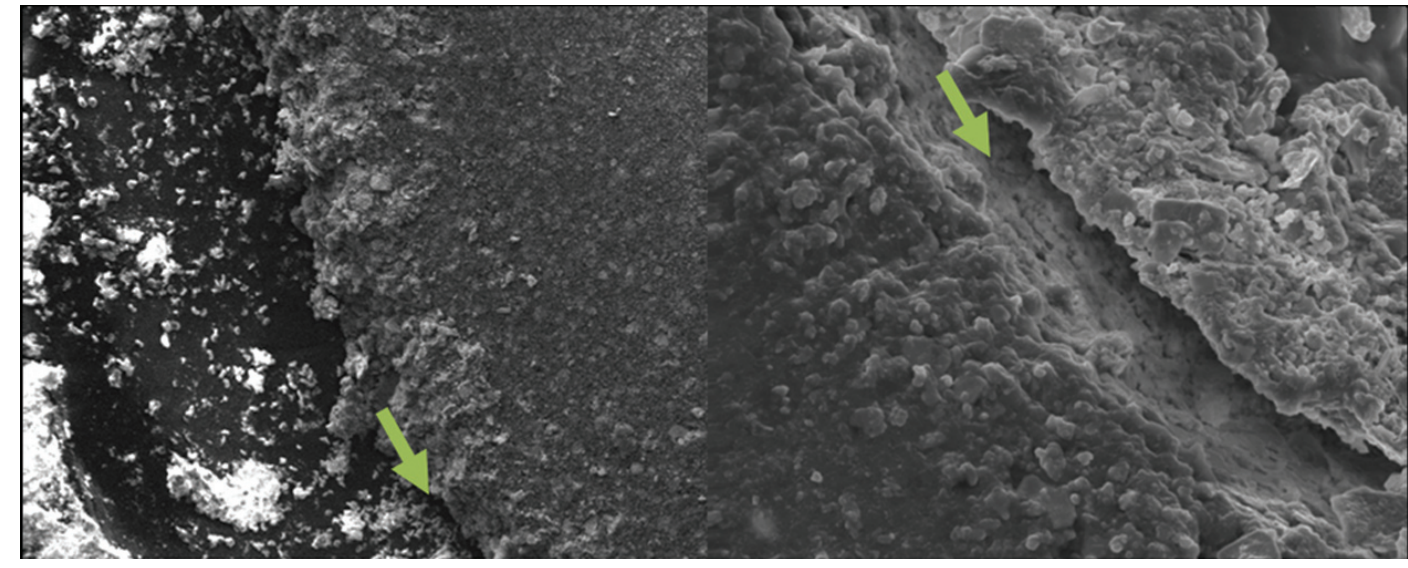

Fig. 2. Interface dentin-sealer AH Plus. Left: 150x; Right: 1000x (SEM).

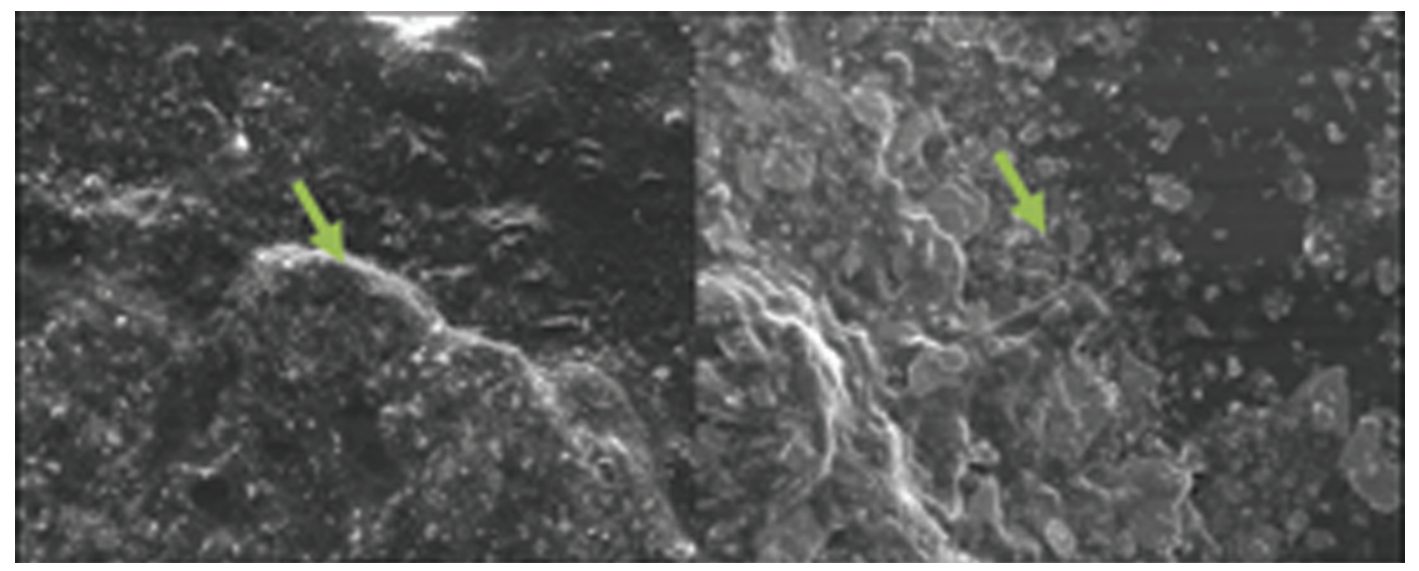

Fig. 3. Interface dentin-sealer RealSeal. Left: 150x; Right: 1000x (SEM).

\section{Discussion}

Adhesion to root dentin has been subject to several debatable issues. Leakage studies using different methods show conflicting results, some unfavorable (12-15) and some favorable (16-18). Together with the question of the usefulness of leakage studies, tooth resilience to adapt to the physiological load thus providing a dynamic status of the interface dentin-sealer, should be taken into consideration. Some studies propose in vivo models, using experimental animals (19). The effect over time also comes into the equation, and yet so far there is no prompt answer as to the best test model.

This study aimed to look at the interface dentin-sealer using SEM. Other studies have also used this method (2). However, the use of pre-defined magnifications (150x and $1000 \mathrm{x}$ ) looking at equidistant areas along the interface and attributing scores is an innovative aspect of this method. We believe this provides a less subjective approach to the observations, which were blinded. Finding the interface dentin-sealer proved straightforward as the delimitation of the area of contact allowed an easy localization even in the absence of gaps.

The increase in magnification, from $150 \mathrm{x}$ to $1000 \mathrm{x}$, did not allow any additional identification of gaps. It could be assumed that 150x is good enough to show defects in the interface dentin-sealer.

RealSeal produced less gaps than AH Plus. There should be caution as to the clinical relevance of this finding, as the samples were not subjected to aging or moisture, being done in ideal conditions. However, it does allow the assumption that some of the advocated properties of Resilon were present. If they resist over time and under clinical conditions is a matter of further investigations. 


\section{References}

1. Skinner RL, Himel VT. The sealing ability of injection-molded thermoplasticized gutta-percha with and without the use of sealers. J Endod 1987;13:315-7.

2. Saleh IM, Ruyter IE, Haapsalo MP, Orstavik D. Adhesion of endodontic sealers: scanning electron microscopy and energy disperse spectroscopy. J Endod 2003; 29:595-601.

3. Orstavik D, Eriksen HM, beyer-Olsen EM. Adhesive properties and leakage of root canal sealers in vitro. Int Endod J 1983;16:59-63.

4. Saunders EM, Saunders WP, Rashid MY. The effect of post space preparation on the apical seal of root fillings using chemically adhesive materials. Int Endod J 1991;24:51-7.

5. Shipper G, Trope M. In vitro microbial leakage of endodontically treated teeth using new and standard obturation techniques. J Endod 2004;30:154-8.

6. Shipper G, Ørstavik D, Teixeira FB, Trope M. An evaluation of microbial leakage in roots filled with a thermoplastic synthetic polymer-based root canal filling material (Resilon). J Endod 2004;30:342-7.

7. Tay FR, Loushine RJ, Weller RN, Kimbrough WF, Pashley DH, Mak Y-F. Ultrastructural evaluation of the apical seal in roots filled with a polycaprolactone-based root canal filling material. J Endod 2005;31:514-9.

8. JR, Wedding Brown JJ, CE, Legan Moore K, Vail MM. An in vitro comparison of microleakage between Resilon and Gutta-Percha with a fluid filtration model. J Endod 2007;33:1447-9.

9. Paqué F, Sirtes G. Apical sealing ability of Resilon/Epiphany versus gutta-percha/AH Plus: immediate and 16-months leakage. Int Endod J 2007;40:722-9.

10. Trope M. Letters to the editor. J Endod 2006;32:85-6.
11. Tay FR. Reply. J Endod 2006;32:85-6

12. Shemesh $H, W u M K$, Wesselink PR. Leakage along apical root fillings with and without smear layer using two different leakage models: a two-month longitudinal ex vivo study. Int Endod 2006;39:968-76.

13. Pitout E, Oberholzer TG, Blignaut E, Molepo J. Coronal leakage of teeth root-filled with gutta-percha or Resilon root canal filling material. J Endod 2006;32:879-81.

14. De Deus G, Audi C, Murad C, Fidel S, Fidel RA. Sealing ability of oval-shaped canals filled using the System B heat source with either gutta-percha or Resilon: an ex vivo study using a polymicrobial leakage model. Oral Surg Oral Med Oral Pathol Oral Radiol Endod 2007; 104:e114-9.

15. De-Deus G, Namen F, Galan J, Jr. Reduced long-term sealing ability of adhesive root-fillings after water-storage stress. J Endod 2008;34:322-5

16. Shin S-J, Jee S-W, Song J-S, Jung I-Y, Cha J-H, Kim E. Comparison of regrowth of Enterococcus faecalis in dentinal tubules after sealing with gutta-percha or Resilon. J Endod 2008; 34:445-8.

17. Zmener $\mathrm{O}$, Pameiher $\mathrm{CH}$, Serrano SA, Vidueira M, Macchi RL. Significance of moist root canal dentin with the use of methacrylatebased endodontic sealers: an in vitro coronal dye leakage study. Endod 2008;34:76-9

18. Wedding JR, Brown CE, Legan JJ, Moore BK, Vail MM. An in vitro comparison of microleakage between Resilon and gutta-percha with a fluid filtration model. J Endod 2007;33:1447-9.

19. Kopper PMP, Figueiredo JAP, Della Bona A, Vanni JR, Bier CA, Bopp S. Comparative in vivo analysis of the sealing ability of three endodontic sealers in post-prepared root canals. Int Endod J 2003; 12:857-63. 